\title{
Islamic Mutual Funds' Financial Performance and International Investment Style: Evidence from 20 countries
}

\author{
Andreas G. F. Hoepner ${ }^{\text {ab }}$, Hussain G. Rammal ${ }^{\mathrm{c}} \&$ Michael Rezec $^{\mathrm{a}}$ \\ ${ }^{a}$ School of Management, University of St. Andrews, The Gateway, North Haugh, St. \\ Andrews, KY16 9SS, UK \\ ${ }^{b}$ Academic Fellow, Principles for Responsible Investment, PRI Secretariat, c/o UN \\ Global Compact, DC2-612, United Nations, New York, NY 10017, US \\ ${ }^{c}$ International Graduate School of Business, University of South Australia, GPO Box \\ 2471, Adelaide, SA 5001, Australia
}

(First version (1.0): August, 2009; this version (3.1): May, 2010)

\begin{abstract}
We pursue the first large scale investigation of a strongly growing mutual fund type: Islamic funds. Based on an unexplored, survivorship bias adjusted dataset, we analyse the financial performance and investment style of 265 Islamic equity funds from twenty countries. As Islamic funds often have diverse investment regions, we develop a (conditional) three level Carhart model to simultaneously control for exposure to different national, regional and global equity markets and investment styles. Consistent with recent evidence for conventional funds, we find Islamic funds to display superior learning in more developed Islamic financial markets. While Islamic funds from these markets are competitive to international equity benchmarks, funds from especially Western nations with less Islamic assets tend to significantly underperform. Islamic funds' investment style is somewhat tilted towards growth stocks. Funds from predominantly Muslim economies also show a clear small cap preference. These results are consistent over time and robust to time varying market exposures and capital market restrictions.
\end{abstract}

Keywords: fund manager learning; home bias; Islamic finance; Islamic mutual funds; responsible investment; three level Carhart model

*Contact Author: School of Management, University of St. Andrews, The Gateway, North Haugh, St. Andrews, KY16 9SS, UK, Email: ah445@st-andrews.ac.uk, Tel: 00441334 462860, Fax: 00441334 462812

Acknowledgements: Our paper substantially benefited from suggestions by Iqbal Asaria, Shahid Ebrahim, John Wilson and two anonymous referees. We would also like to thank Mohsen Derregia, Dewi Fitriasari, Phil Molyneux and seminar participants at Nottingham, St. Andrews and the Emerging Scholars in Banking and Finance conference at Cass Business School for their comments. Finally, we are very grateful to Andrew Gibson Miller of Eurekahedge and Robert Schwob of Style Research Limited for provision of data. All remaining errors are our sole responsibility. The views expressed in this paper are not necessarily shared by the Principles for Responsible Investment. 


\section{Introduction}

An important contemporary issue for financial institutions and financial markets are Islamic financial services, which are rapidly growing worldwide. In 2007, Islamic law (Shari'ah) compliant assets are estimated to have grown by $37 \%$ to $\$ 729 \mathrm{bn} .{ }^{1}$ They are expected to reach the $\$ 1$ trillion mark in 2010. While many assets are based in countries like Saudi Arabia, Malaysia or Kuwait, western financial institutions and governments have also developed a strong interest in Islamic finance (Cihák and Hesse 2008; McKenzie 2009). The British government praises the UK as 'the leading centre for Islamic finance outside of the Gulf Cooperative Council [GCC] and Malaysia' and has defined clear policy objectives for its development (HM Treasury 2008, 5). The UK is the world leader for Islamic finance education. Islamic financial services are offered in Britain by nearly two dozen banks including Barclays, HSBC, Lloyds, and RBS. The market leader, HSBC's Islamic finance division Amanah, has realised an annual asset growth of more than 50\% in 2007/08. As Shari'ah law prohibits many high risk activities, Islamic financial services have been much less affected by the credit crisis than their conventional counterparts, which adds to their appeal. Western countries like the US, France, Germany or Switzerland are also promoting their Islamic financial services to attract especially petro-dollars (McKenzie 2009).

One multibillion dollar industry within Islamic finance is Islamic investment. Dow Jones, FTSE, MSCI Barra and Standard \& Poor's offer hundreds of Islamic equity indices. Similarly, more than seven hundred Islamic mutual funds are currently offered, which specialise in a variety of different assets (e.g. equities, Islamic bonds,

\footnotetext{
${ }^{1}$ The estimated growth is partly related to an extended estimation coverage. Nevertheless, Islamic financial services' market value was only about \$150bn in the mid 1990s. Hence, it grew nearly $400 \%$ until the end of 2007 with average annual growth rates of about 14\% (McKenzie 2009).
} 
real estate, commodities). The few previous studies of their financial performance investigate samples of less than sixty funds and also lack nearly any control for investment style. In this study, we utilise the largest existing dataset of Islamic funds (which is unexplored to date) to analyse 265 Islamic equity funds from twenty countries over a twenty year sample period. Specifically, we investigate the following research questions:

(1) Does the financial performance of Islamic equity mutual funds significantly differ from the respective equity market benchmark(s)?

(2) Which investment styles are preferred by Islamic equity mutual funds?

(3) If national differences exist in Islamic equity funds' financial performance and investment style, how can these be explained?

Based on a standard Carhart model, we find more than half of our equal weighted national Islamic equity fund portfolios to significantly underperform their national equity market benchmarks. At national level, Islamic funds display a tilt towards growth and small cap stocks. However, Islamic mutual funds from the same country tend to invest in a variety of different international regions. Hence, we cannot sufficiently assess their financial performance and investment style without controlling for their exposure to regional and global equity market benchmarks and investment styles. To control for these regional and global factors, we also develop a three level Carhart model, which uses twelve factors to control for equity market and investment style exposure at three levels: (i) in a nation, (ii) in all other nations of a region, (iii) and in all other regions of the world.

This more sophisticated three level Carhart factor model leads to considerably different results. We find only two fifth of our national Islamic equity fund portfolios to significantly underperform international equity benchmarks, while a quarter of 
them significantly outperforms. Islamic funds' preference for growth stocks weakens in the twelve factor model and only funds from predominantly Muslim economies are still tilted towards small cap stocks. These results are consistent over time and robust to time varying market exposures and capital market restrictions.

Interestingly, clear systematic national differences appear in our results. We find Islamic funds from the six largest Islamic financial centres in our study (the GCC countries and Malaysia) to perform competitive to international equity market benchmarks. Two of these nations' Islamic fund portfolios even significantly outperform. In contrast, Islamic fund portfolios from most other nations with often barely developed Islamic financial services significantly underperform their benchmarks. This result can be explained with learning effects resulting from the development of markets, which have also been found for conventional mutual funds (Christoffersen and Sarkissian 2009).

The nations with lesser developed Islamic financial services can further be structured in two groups. While the fund portfolio from only one of the predominantly Muslim countries among these nations significantly trails its benchmarks, Islamic funds from seven western nations underperform on average. This implies that incorporation in an Islamic economy benefits Islamic funds' financial performance. As funds from Islamic economies tend to have a home bias, a possible reason for this relevance of home country religion might be that the financial value of a stock's Shari'ah compliance is positively related to the influence of Shari'ah law on consumers in its home economy. We find support for this explanation in our observation that Islamic funds from those Islamic economies perform best, whose dominant Islamic school of thought most literally follows the letters of Qur'an. 
The home bias of funds from Islamic economies with often comparatively small corporations can also explain why these funds exhibit a small cap preference at regional and global level in contrast to the remaining funds. Their small cap investment style at national level might result from larger corporations being usually more diversified, which increases the risk that they operate in sectors forbidden by Shari'ah law.

We structure our text as follows: Section 2 provides a brief background on Islamic mutual funds. Section 3 describes our Islamic fund and benchmark data. Section 4 presents the methods and discusses the results of our main analyses. Section 5 covers our robustness test, before Section 6 concludes.

\section{Background}

The background section starts with a brief discussion of relevant characteristics of Islamic mutual funds. Subsequently, we discuss Islamic funds' financial performance and investment style from a theoretical and from an empirical perspective.

\subsection{Islamic mutual funds}

Islamic funds are defined by their compliance with Islamic law, commonly known as Shari'ah law. '[W]hile Islam promotes improving ones economics condition, it has to be done within a framework of good values and good economic/business practices' (Ebrahim 2008, 118). Inter alia, Shari'ah law prohibits mutual funds from Riba al Nasiah, Maysir, Gharar, and Haram products or services and it requires Haram purifcation.

Riba al Nasiah represents the receipt of interest on capital. Hence, Islamic mutual funds cannot invest in conventional bonds, warrants, preferred stock, certificates of deposit and some derivatives. Maysir and Gharar can be translated as gambling and uncertainty, respectively. Their prohibition commonly prevents Islamic 
funds from leverage, short selling and any derivate product. In addition to Riba al Nasiah, Maysir, and Gharar, products or services that adversely affect dignity or promote the exploitation of one another are Haram (forbidden). Examples are pork, (non-medical) alcohol, gambling, non-Islamic financial services, pornography, tobacco or weapons. Given the sheer size of contemporaneous multinational companies, many of them receive (very) small proportions of their revenue from a prohibited activity. Contemporary Shari'ah scholars therefore tend to allow investment in stocks with tolerable proportions of revenues from prohibited activities under the condition of Haram purifcation. ${ }^{2}$ This condition requires investors to donate the equivalent proportion of their distributions from such companies to charities to purify their earnings from prohibited activities (Derigs and Marzban 2008; Ebrahim and Rahman 2005; El-Gamal 2006; Jaffer 2004; Rahail 2008).

\subsection{Theoretical perspectives on Islamic funds' financial performance and investment style}

Several theoretical implications result from Shari' ah law and demographics of Islamic funds. First, Islamic mutual fund managers are restricted in their ability to exploit superior information or winning markets (e.g. using leverage). However, the average mutual fund manager has not been found to display superior skills (Bollen and Busse 2001; Kosowski et al. 2006). Hence, the opposite argument might also apply that Shari'ah law limits the potential damage caused by a manager (Abdullah, Hassan and Mohamad 2007).

Second, like socially responsible investment, Shari'ah compliant investment refuses to purely pursue profits. Some argue that such a distraction by concerns about responsibility would be detrimental for financial performance (e.g. Geczy, Stambaugh

\footnotetext{
${ }^{2}$ The Shari'ah Supervisory Board of the Dow Jones Islamic Index, for instance, tolerates corporations, whose ratios of total debt, sum of cash and interest bearing security, and accounts receivable are less than a third of the corporation's market capitalisation (Dow Jones 2009). Other Islamic indices use similar ratios (Derigs and Marzban 2008).
} 
and Levin 2005). They are supported by evidence suggesting standard sin stocks (alcohol, gambling, tobacco) excluded by Islamic funds to deliver significantly positive abnormal returns (Hong and Kacperczyk 2009). However, others consider responsible, non-financial investment criteria to represent advanced risk management (e.g. Lee and Faff 2009). Evidence to support this argument comes from the cases of Enron, Tyco and Worldcom. Before their scandals, these companies were excluded from the Dow Jones Islamic Market Index (Ghoul and Karam 2007).

Third, the Shari'ah compliance of products and services is likely financially more beneficial in economies, whose customers and agents experience a higher utility from adherence to Shari'ah law. Hence, Islamic mutual funds might experience a better financial performance in predominantly Muslim economies than elsewhere. Fourth, Christoffersen and Sarkasian (2009) find financial centres with a high density of financial intermediaries and competitors to have a significantly positive effect on mutual fund managers' learning gains and their eventual financial performance. They explain the performance relevance of being located in a financial centre with better information and knowledge spillover effects. If such learning processes also drive Islamic funds' financial performance, we expect funds from nations with the most developed Islamic financial markets to perform better than their peers elsewhere.

Fifth, Islamic mutual funds' investment styles are probably more homogeneous than their conventional counterparts' styles due to Shari'ah law's narrow framework of eligible activities. Islamic funds could have somewhat lower betas than conventional, possibly leveraged funds. Islamic funds also likely invest over-proportionally in smaller stocks, as large stocks have a higher risk of receiving intolerable revenues from prohibited activities. Similarly, we expect Islamic funds to be more exposed to growth stocks than value stocks, as the former are considered to 
have a lower leverage than the latter (Campbell and Vuolteenaho 2004). However, we cannot see any theoretical reason, why Islamic funds should be more exposed to momentum than contrarian investment strategies or vice versa.

\subsection{Empirical indications on Islamic funds' financial performance and investment style}

Empirical evidence on Islamic funds is scarce with extant studies analysing the financial performance of less than sixty funds (Abderrezak 2008; Abdullah, Hassan and Mohamad 2007; Elfakhani, Hassan and Sidani 2005; Kraeussl and Hayat 2008). The longest investigation to date has been undertaken by Abdullah et al. (2007). They estimate the Jensen (1968) alpha of a portfolio of fourteen Malaysian Islamic funds over the period from 1992 to 2001 and find these to significantly underperform the market benchmark. Three other studies investigate samples of less than six years and face challenges in their fund or benchmark data:

Kraeussl and Hayat (2008) estimate Jensen alphas for 59 international Islamic equity funds identified via Bloomberg over the five year period to August 2006. They find their 31 Malaysian funds to significantly underperform the respective equity market benchmark, while 21 globally investing funds had an insignificant performance difference and 7 'other' funds even significantly outperformed their market benchmark. However, their results have to be interpreted with some care, as they had to replace missing net asset values by the average of the previous and subsequent observation.

Elfakhani et al. (2005) investigate 46 international Islamic funds identified by Falaika or Standard \& Poors (S\&P) over a 68 months sample to August 2002. As they regress their international Islamic funds on the S\&P 500, their results are mainly meaningful for their portfolio of seven North American funds, whose alpha is insignificant. Using sensibly matched equity market benchmarks, Abderezzak (2008) 
re-investigates Elfakhani et al.'s (2005) sample and finds only Asian domestic funds to significantly underperform.

Contrary to the other studies, Abderezzak (2008) investigates Islamic funds' investment styles in addition to their financial performance for a sub-sample of 19 US, European or global funds. But as his data access is limited to two US investment style benchmarks, his results are only fully sensible for his six US funds. Four of these six funds display the expected small cap style, while the six funds have no clear preference for a value or growth style.

In summary, previous studies provide some indication that a few Islamic mutual funds might trail their conventional benchmarks and display a preference for small cap stocks. However, the financial performance and investment style of hundreds of Islamic mutual funds is unexplored to date. ${ }^{3}$ Consequently, we consider our analysis of 265 funds from twenty countries to be the first large scale investigation of Islamic equity mutual funds' financial performance and investment style.

\section{Data}

Data is the main shortage in analyses of Islamic mutual funds. Previous studies lacked time series data on both, hundreds of Islamic mutual funds and international investment style benchmarks. We address both shortages. In the first part of this section, we analyse the descriptive statistics of our sample of 265 Islamic equity funds from twenty countries. Since the characteristics of these twenty countries could explain differences in Islamic funds' financial performance and investment style, we

\footnotetext{
${ }^{3}$ The literature on Islamic investment indices is somewhat more extensive. Most notably, Derigs and Marzban (2009) find ex-post optimised Shariah compliant indices to deliver a lower financial return than ex-post optimized conventional indices. Forte and Miglietta's (2007) results highlight the unique characteristics of Islamic investments, as they do not observe FTSE's Islamic index to be significantly cointegrated with its socially responsible or conventional counterpart. Girard and Hassan (2008), however, do not find international FTSE Islamic indices to trail their conventional peers. These three papers are recommended as gateway into this literature.
} 
analyse our sample countries' financial market and Islam related properties in the second part. The third part describes our international investment style benchmarks.

\subsection{Islamic mutual fund data}

As of May 2009, we have access to by far the largest, worldwide database of Islamic mutual funds: Eurekahedge. It currently lists 758 Islamic mutual funds (alive or dead), which more than doubles the funds listed on Falaika, the only other provider of return data on hundreds of Islamic funds. 455 of these funds are equity funds. ${ }^{4}$ Of these equity funds, Eurekahedge reports monthly return data for 304. However, in a few dozen cases, Eurekahedge lists several asset classes of the same mutual fund. In these cases, we follow Da et al. (2009) and calculate an equal weighted average of these fund classes' simple returns. This leaves us with a survivorship bias adjusted sample of 265 Islamic equity mutual funds, whose monthly return data we convert in US\$. Our sample starts with the launch of the first Islamic mutual fund in September 1990 and ends April 2009. As Islamic mutual funds are spread over all continents except Latin America, our sample has a wide geographic distribution. It includes funds from the following five regions and twenty countries: (i) Africa: Egypt, Morocco, South Africa, (ii) Asia-Pacific: Australia, Indonesia, Malaysia, Pakistan, Singapore (iii) Europe: Germany, Ireland, Liechtenstein, Luxembourg, UK (including British Virgin, Cayman and Channel Islands), (iv) Gulf Cooperative Council (GCC): Bahrain, Kuwait, Qatar, Saudi Arabia, UAE, (v) North America: Canada, US.

Based on Eurekahedge's simple return data, we construct equal weighted fund of fund portfolios for each nation. ${ }^{5}$ This leads to twenty national portfolios, whose

\footnotetext{
${ }^{4}$ We follow Bollen (2007) and Renneboog et al. (2008) by defining an equity mutual funds as investing at least $75 \%$ in stocks. As Eurekahedge does not provide asset allocation data for Islamic funds, our sample comprises all funds classified by Eurekahedge as equity as well as all of Eurekahedge's balanced funds, whose benchmark consist to at least $75 \%$ of an equity index.

${ }^{5}$ It is common practice to analyse portfolios of assets with religious of ethical characteristics based on equal weighted rather than value weighted portfolios. This practice ensures a focus on the assets
} 
continuously compounded monthly returns are computed subsequently. Eurekahedge's simple return data is supplied net of annual management fees but it unfortunately excludes distributions. This is a considerable problem, as estimating mutual funds' financial performance using return data excluding distributions against common market benchmarks, whose return data includes distributions, would lead to significantly downwards biased financial performance estimates. Hence, our investigation of our first research question, if the financial performance of Islamic equity mutual funds significantly differs from the respective equity market benchmark(s), lacks considerable reliability unless we can sufficiently address this problem. Unfortunately though, Islamic mutual fund data is generally exposed to this problem, as the return data offered by Eurekhedge's only competitor, Falaika, does not consider distributions either (Abderrezak 2008). Thus, this limitation cannot be overcome, as any current analysis of hundreds of Islamic mutual funds is inevitably exposed to it. However, we can mitigate the effect of this limitation and investigate the remaining loss of information value.

We mitigate the effect of this limitation by using benchmark return data exclusive of dividends, which ensures that our estimated Islamic fund performance is not systematically downwards biased. We investigate any possibly remaining systematic loss of information value by estimating the financial performance of Islamic funds with our main regression model presented in equation (3) based on fund and benchmark return data (i) exclusive and (ii) inclusive of distributions. For four British, four Luxembourgian and five US Islamic funds with Eurekahedge plain return

religious or ethical characteristics and substantially reduces the risk of bias due to idiosyncratic return characteristics of a specific asset (Hong and Kacperczyk 2009; Renneboog, Ter Horst and Zhang 2008). In case of Islamic mutual funds, the available data furthermore does not allow for a precise computation of value weighted portfolios. Eurekahedge, for instance, provides only static fund size data, which is very generously rounded and somewhat incomplete. 
data, we can retrieve fund prices net of annual management fees and inclusive of distributions from Datastream.

Based on these funds, we calculate equal weighted returns of a British, Luxembourgian and US national fund portfolio excluding and including distributions. Based on return data exclusive of distributions, our financial performance estimates of the British, Luxembourgian and US Islamic fund portfolio are -0.0134 (1\% significant), -0.0034 (5\% significant) and -0.0055 (1\% significant), respectively. Based on return data inclusive of distributions, the financial performance estimates of our British, Luxembourgian and US Islamic fund portfolio are -0.0161 (1\% significant), -0.0090 (5\% significant) and -0.0133 (1\% significant), respectively. As the financial performance estimates' size differs between the estimation exclusive and inclusive of distributions, we recommend care in the interpretation of the size of our financial performance estimates based on Eurekahedge's data. Most importantly, however, we find the significance level of our financial performance estimates to be unaffected by the current impossibility to access return data inclusive of distributions for hundreds of Islamic funds.

In summary, while information value is lost due to the fact that Eurekahedge's return data does not include distributions with regard to the precise size of financial performance estimates, no meaningful information value appears lost regarding the significance level of financial performance estimates. Thus, we consider an investigation of our first research question, if the financial performance of Islamic equity mutual funds significantly differs from the respective equity market benchmark(s), based on Eurekahedge's return data to be reliable.

Descriptive statistics for our Islamic mutual fund portfolios are shown in Table 1. Over $90 \%$ of our funds are domiciled in the Asia- Pacific (42.6\%), GCC 
$(34.0 \%)$, or European (17.0\%) regions. Each region is dominated by a particular country (Malaysia, Saudi Arabia, UK). The UK with its overseas territories hosts the third highest percentage of our sample funds (about 9\%), which highlights its relevance in the market for Islamic mutual funds. Most countries have relatively low mean and lower median funds ages, which reflects the youth of the industry. ${ }^{6}$ Large funds of hundreds of millions of US\$ exist to date only in Saudi Arabia, Malaysia and the US.

The average Islamic equity fund prefers to invest globally, in the Asia-Pacific region or in the GCC countries. However, Islamic funds from the same nation tend to invest in a variety of different regions. For instance, most funds from Saudi Arabia invest in the GCC countries or globally, but some focus their investment on the Asia Pacific region, on Europe or on North America. British, German and Irish Islamic funds have especially diverse geographic investment foci. A substantial part of them focuses its investment on the Asia-Pacific region or the Middle East. This diversity in geographic investment focus implies that assessing Islamic funds' financial performance only with national, regional or global benchmarks does not fully capture their equity market exposure.

Approximately $9 \%$ of our sample funds have died. This is somewhat below the annual attrition rates found for conventional mutual funds and might reflect the strong recent growth in Islamic financial services (Carhart et al. 2002). However, attrition rates vary considerably between our sample countries. While attrition rates in

\footnotetext{
${ }^{6}$ In case of two countries (Liechtenstein, Qatar), our dataset comprises more than twenty but less than thirty observations. Thirty observations are commonly considered to be the minimum threshold to assume an approximately normal distribution of OLS regression residuals based on the central limit theorem. Since we cannot assume a normal distribution of regression residuals for these two countries, we pursue Jarque Bera (1987) tests of the normality of these nations' regression residuals in all our main estimation models. Our results do not allow us to reject the normality of the regression residuals in any specification even at the lenient $10 \%$ significant level. Hence, we assume the residuals of our regressions for Liechtenstein and Qatar to be approximately normally distributed based on our tests instead of the central limit theorem.
} 
most nations are very low, a quarter of our sample countries including the UK have attrition rates of over 20 percent, which likely has a negative effect on the financial performance of these nations' Islamic fund portfolios.

[Insert Table 1 about here]

\subsection{Sample country characteristics}

Since national differences in Islamic funds' financial performance and investment style might result from national characteristics, Table 2 provides an overview on our sample countries' relation to Islam and their financial markets. The population of half of our sample countries is predominantly Muslim. All of these countries but Indonesia incorporate Islam in their constitution. However, differences exist in the predominant school of Islamic thought. For instance, Saudi Arabia and Qatar follow the Hanbali school with its literal interpretations of Quran, while Pakistan is dominated by the liberal Hanafi school. Islamic financial markets with assets worth more than $\$ 10 \mathrm{bn}$ exist in seven sample countries. The largest six of these financial markets are all located in the Islamic world (Bahrain, Kuwait, Malaysia, Saudi-Arabia, UAE, and Qatar). The seventh largest Islamic financial market is the UK. Interestingly, the UK is the only predominantly Christian country in this group and also represents the only developed Islamic financial market with Islamic fund attrition rates over 20 percent. This observation suggests that Islamic investment services might develop smoother in Muslim economies.

Assets in predominantly Islamic economies are often, but not necessarily, more likely Shari'ah compliant. While the vast majority of Muslim economies hosts Shari'ah compliant assets over-proportionally, Morocco's and the UAE's financial markets comprise a slightly under-proportional degree of them. Similarly, many 
Christian economies' assets are clearly under-proportional Shari'ah compliant, whereas Canada and South Africa host compliant assets over-proportionally.

Table 2 also displays relevant financial market restrictions, which limit inbound or outbound investment during our sample period. Outbound restrictions limit the ability of a mutual fund to invest abroad and directly affect its international investment style and likely also financial performance. Inbound restrictions limit foreigners to invest in the respective nation. They indirectly affect the investment style and financial performance of the nation's mutual funds, as they often substantially restrict the demand of national assets. Hence, Islamic funds from economies with inbound restrictions tend to operate in less competitive but also less liquid national stock markets. Malaysia, Morocco and South Africa are the only countries in our sample to impose outbound restrictions. In contrast, inbound restrictions are more common. They have been or are in place in all GCC countries, Egypt, Indonesia, Malaysia, Pakistan and Singapore.

\section{[Insert Table 2 about here]}

\subsection{Benchmark Data}

We construct our benchmark factors with the online research tool of Style Research Limited, which is based on the Worldscope database and has been used in previous research (Bauer, Koedijk and Otten 2005; Renneboog, Ter Horst and Zhang 2008).

To assess Islamic mutual funds exposure to a national, regional and global equity market, we employ the price indices of value weighted portfolios of all stocks in the respective market. ${ }^{7}$ We use the common investment style benchmark factors suggested by Fama and French (1993) and Carhart (1997). These measure a

\footnotetext{
${ }^{7}$ Style Research Limited provides return indices, which assume distributions to have been reinvested, and dividend yields but no price indices. However, as discussed in the previous section, we require equity market returns exclusive of dividends to match these to our Islamic mutual fund returns. Hence, we manually compute price indices by reducing the return indices by the monthly reinvested dividend yield.
} 
portfolio's exposure to equities with a different size, book value to market value ratio, and momentum. We construct benchmark factors for each style at the national, regional and global level. The size factor SMB (Small minus Big) is constructed as the return difference between the stocks in the lower half of a market capitalization ranked stock universe and the stocks in the upper half of the same universe. The book to market ratio factor HML (High minus Low) is based on a stock universe ranked according to book value to market value ratio. It represents the return of the Top $30 \%$ minus the Bottom 30\%. The momentum factor MOM is based on a stock universe ranked according each stock's return over the previous twelve months. It represents the return difference between the Top 30\% (previous winners) and the Bottom 30\% (previous losers). The MOM factor is updated monthly, while the SMB and HML factor are update annually at the end of June in line with Fama and French (1993). All portfolios are value weighted and based on one month lagged information. ${ }^{8}$ As risk free asset returns, we retrieve the one or three month(s) treasury-bill or the inter-bank interest rate for each nation. ${ }^{9}$ Finally, we compute continuously compounded monthly returns of each asset. ${ }^{10}$

\section{Analysis, results and discussion}

We present and discuss our results in order of increasing sophistication of our econometric model. We start with the CAPM and Carhart model and proceed to the unconditional and conditional three level Carhart model.

\footnotetext{
${ }^{8}$ As Style Research does not offer the construction of the size and book to market factor precisely according to Fama and French (1993), we follow Renneboog et al.'s (2008) slightly amended procedure. Renneboog et al. $(2008,307)$ find that their 'factors are virtually identical' to the ones of Fama and French (1993).

${ }^{9}$ Matching Islamic equity mutual funds against conventional equity mutual funds as common in the socially responsible investment literature (e.g. Kreander et al. 2005) is not possible for large parts of our sample, as the usual databases do cover an insufficient number of conventional mutual funds from many nations in Asia or Africa.

${ }^{10}$ As we do not have sufficient data on any benchmark asset for Liechtenstein, we employ Germany's benchmark assets for it. For Luxembourg, we employ the equity market benchmark and the investment style benchmarks of the Benelux countries due to the same reason.
} 


\subsection{CAPM and Carhart model}

We start our analysis by estimating a simple national Capital Asset Pricing Model (CAPM) as specified in equation (1),

$r_{p, t}=\alpha_{p}+\beta_{n a t, p} r_{n a t m, t}+\varepsilon_{p, t}$

where $r_{p, t}$ and $r_{n a t m, t}$ represent the excess return of a portfolio (p) and the national equity market benchmark (natm) over the risk free asset return $\left(\mathrm{r}_{\mathrm{f}}\right)$, respectively. $\beta_{\mathrm{nat}, \mathrm{p}}$ is the portfolio's systematic exposure to the national equity market benchmark. $\alpha_{\mathrm{p}, \mathrm{t}}$ denotes Jensen's (1968) Alpha, which can be interpreted as portfolio's systematic return component above or below the return achieved by the equity market benchmark for the same level of systematic risk. $\varepsilon_{\mathrm{p}, \mathrm{t}}$ captures the random components of a portfolio's excess return for each observation (t) (Lintner 1965; Mossin 1966; Sharpe 1964).

As shown in Table 3, we find nine of our twenty countries' Islamic equity fund portfolios to experience significantly negative Jensen Alphas (Egypt, Germany, Liechtenstein, Luxembourg, Morocco, Saudi Arabia, South Africa, UK and US). In contrast, not a single nation's Islamic funds outperform the market benchmark on average. If our subsequent, more robust estimations would lead to similar results, the theoretical view would be supported that Shari'ah law restricts fund manager skills or distracts mutual funds from the pursuit of profits. All Islamic mutual fund portfolios' betas are significantly below one. This is likely explained by two characteristics of Islamic equity funds. First, the vast majority of Islamic funds do not appear to limit their investment to their national boundaries. Second, Shari'ah law forbids Islamic funds to use leverage in their investment strategies.

[Insert Table 3 about here] 
To investigate the national investment style of Islamic equity funds, we estimate a Carhart (1997) model, which adds the national investment style benchmark factors $\mathrm{SMB}_{\text {nat, }, \mathrm{t}} \mathrm{HML}_{\text {nat, } \mathrm{t}}$ and $\mathrm{MOM}_{\text {nat, } \mathrm{t}}$ to our CAPM as shown in equation (2),

$r_{p, t}=\alpha_{p}+\beta_{\text {nat }, p} r_{\text {natm }, t}+\gamma_{\text {nat }, p} S M B_{n a t, t}+\delta_{\text {nat }, p} H M L_{n a t, t}+\lambda_{\text {nat }, p} M O M_{n a t, t}+\varepsilon_{p, t}$

where $\gamma_{\text {nat,p }}, \delta_{\text {nat,p }}$, and $\lambda_{\text {nat,p }}$ measure the exposure of a portfolio to the respective investment style.

Our results are presented in Table 3. They show that more than half of our twenty countries' Islamic equity fund portfolios significantly underperform after controlling for national investment style. The eleven underperforming national portfolios predominantly originate from Africa (Egypt, Morocco, South Africa), Europe (Germany, Liechtenstein, Luxembourg, UK) and North America (Canada, US). Only one national portfolio from Asia (Malaysia) or the GCC countries (Saudi Arabia) underperforms after controlling for national investment styles.

Our controls allow us to explain substantially more of the return behaviour of several countries' Islamic fund portfolios (e.g. Bahrain, Morocco). In terms of style, we find more than half of our Islamic fund portfolios to display a significantly overproportional investment in national small cap stocks. We expected this result, since large, often well diversified companies have a higher risk of receiving intolerable proportions of their revenue from prohibited activities. Islamic funds are also tilted towards growth stocks. This might result from the lower leverage of growth stocks compared with value stocks. Regarding a momentum or contrarian investment style, we neither theoretically reasoned nor empirically observe any systematic preference.

\subsection{Three level Carhart model}

As Islamic funds from the same nation invest in a variety of regions, national, regional, or global benchmark factors alone do not offer a full picture of their 
financial performance and investment style. However, the Carhart (1997) model is commonly applied only at one level: the national, regional or global.

Gregory and Whitaker $(2007,1327)$ recently 'propose a new measure for the performance of international funds', which represents a Carhart model at the national and global level. They construct an eight factor model by adding the difference returns between each of the four national benchmark factors and its global counterpart to a global Carhart model. Correcting a national factor for the influence of its global equivalent is very important to avoid a high correlation between both factors and hence potential multicollinearity bias in a regression's results.

Gregory and Whitaker's subtraction of a global factor from a national factor can mitigate multicollinearity problems in several cases. However, it does not ensure the absence of (strong) multicollinearity, as it does not account for the degree, to which a global factor affects its national counterpart. Precisely, Gregory and Whitaker's subtraction under- (over-) corrects the national factors, if a single regression of the national factor on the global factor results in a coefficient of above (below) one. The size of this under- or overcorrection subsequently determines the probability of multicollinearity problems in Gregory and Whitaker's model. ${ }^{11}$

A precise statistical correction for the influence of a global factor on its national equivalent is offered by Elton et al.'s (1993) orthogonalization approach. This approach cleans a factor $\mathrm{X}$ from the impact of other factors $\mathrm{Y}$ by regressing it on them and replacing factor $X$ by the sum of the intercept and the residuals of the regression. This ensures that the correlation between the cleaned $\mathrm{X}$ factor and factors $\mathrm{Y}$ is asymptotically zero. For instance, if we orthogonalized the return of the UK

\footnotetext{
${ }^{11}$ For instance, in case the global factor and the national factor were perfectly correlated, whereby the absolute returns of the global factor would always be half of the national factor's returns, subtracting the global from the national factor would lead to a corrected national factor, which is identical to the global factor. Hence, multicollinearity problems would be certain in this case.
} 
equity market from the return of the world equity market, the resulting cleaned UK equity factor would comprise purely UK specific return characteristics.

Based on these ideas of Gregory \& Whitaker (2007) and Elton et al. (1993), we develop a three level Carhart model, which simultaneously assesses the financial performance and investment style of an asset at the national, regional, and global level. Our baseline model is a national four factor Carhart model. To this model, we add the same four regional factors, which have been orthogonalized from their national equivalents $\left(r_{\text {regm,t }}, \mathrm{SMB}_{\text {reg,t, }}, \mathrm{HML}_{\text {reg,t }}\right.$ and $\left.\mathrm{MOM}_{\text {reg, }, \mathrm{t}}\right)$. We extend the resulting eight factor model to a twelve factor model by adding the same four global factors, which have been orthogonalized from their national and regional counterparts $\left(\mathrm{r}_{\mathrm{glom}, \mathrm{t}}, \mathrm{SMB}_{\mathrm{glo}, \mathrm{t}}, \mathrm{HML}_{\mathrm{glo}, \mathrm{t}}\right.$ and $\left.\mathrm{MOM}_{\mathrm{glo}, \mathrm{t}}\right) .{ }^{12}$ The result is our three level Carhart model as displayed in equation (3),

$$
\begin{aligned}
& r_{p, t}=\alpha_{p}+\beta_{\text {nat }, p} r_{\text {natm }, t}+\beta_{\text {reg }, p} r_{\text {regm }, t}+\beta_{\text {glo }, p} r_{\text {glom }, t}+\gamma_{\text {nat }, p} S M B_{\text {nat }, t}+\gamma_{\text {reg }, p} S M B_{\text {reg }, t} \\
& +\gamma_{\text {glo }, p} S M B_{\text {glo }, t}+\delta_{\text {nat }, p} H M L_{\text {nat }, t}+\delta_{\text {reg }, p} H M L_{\text {reg }, t}+\delta_{\text {nat }, p} H M L_{g l o, t}+\lambda_{\text {nat }, p} M O M_{\text {nat }, t} \\
& +\lambda_{\text {nat }, p} M O M_{\text {reg }, t}+\lambda_{\text {nat }, p} M O M_{\text {glo }, t}+\varepsilon_{p, t}
\end{aligned}
$$

where the subscripts nat, reg, or glo indicate that a factor or coefficient represents the national, regional, or global level, respectively. ${ }^{13}$

As shown in Table 4, our three level Carhart models have in most cases substantially higher adjusted R-squared than our national Carhart models. The additional explanatory power of our model is particularly strong for those national portfolios from the GCC countries or Europe, whose geographic investment foci are especially diverse. For instance, the adjusted R-squared of the Bahrain, Saudi Arabia, Ireland and UK portfolio rise from $0.465,0.418,0.570$ and 0.728 in the national Carhart model to $0.888,0.843,0.794$ and 0.890 in our three level Carhart model,

\footnotetext{
${ }^{12}$ As our baseline model is a national four factor Carhart model, we expect the coefficients of the orthogonalized regional and global factors in our three level Carhart model to be more variable than their national equivalents.

${ }^{13}$ The other symbols in equation (3) are defined equivalent to the previous equations.
} 
respectively. These results highlight the strength of the three level Carhart model, which hence might be informative to many other applications of asset pricing or investment beyond Islamic mutual funds.

Controlling for Islamic mutual funds' international investment style explains a substantial part of their significant negative abnormal returns. Only seven of the eleven portfolios with a significantly negative Jensen alpha in their national Carhart model (Germany, Liechtenstein, Luxembourg, Morocco, South Africa, UK, US) and Australia underperform in our three level Carhart model. Four portfolios significantly outperform (Ireland, Qatar, Singapore, UAE). The remaining eight national portfolios, which comprise $74.3 \%$ of the funds in our sample (i.e. 197 of 265 funds), display a financial performance statically indifferent from international equity benchmarks (Bahrain, Canada, Egypt, Indonesia, Kuwait, Malaysia, Pakistan, Saudi Arabia). Based on these results, we cannot conclude anymore that Islamic funds generally underperform their equity market benchmarks. Hence, while the theoretical view that Shari'ah compliance distracts Islamic mutual funds' from the pursuit of profit might apply to some of our sample funds, it appears too simplistic to generally explain international Islamic equity fund performance.

Instead, our results imply that Islamic funds' financial performance might be conditional on two national characteristics. First, Islamic equity fund portfolios from the six countries with the best developed Islamic financial markets (Bahrain, Kuwait, Malaysia, Qatar, Saudi Arabia, UAE) do not deliver significantly negative abnormal returns and in the cases of Qatar and UAE even outperform their international benchmarks. In contrast, Islamic funds from eight of the fourteen countries with lesser developed Islamic financial markets in our sample significantly trail their benchmarks (Australia, Germany, Liechtenstein, Luxembourg, Morocco, South Africa, UK, US). 
This result implies that the development of Islamic financial centres has a positive effect on Islamic fund performance. A very similar finding has recently been made by Christoffersen and Sarkasian (2009) for conventional financial centres and mutual funds. Following their in-depth explanation, we assume that the high density of intermediaries and competitors in the six Islamic financial centres has a positive effect on Islamic fund managers' learning gains and eventually on their funds' performance.

Second, among the fourteen nations with the lesser developed Islamic financial markets in our sample, the fund portfolios from seven predominantly Christian economies significantly underperform their international benchmarks (Australia, Germany, Liechtenstein, Luxembourg, South Africa, UK, US). In contrast, the fund portfolio from only one of the four predominantly Muslim economies in this group underperforms (Morocco). This implies that incorporation in an Islamic economy benefits Islamic funds' financial performance. As funds from Islamic economies tend to have a home bias similar to the one of conventional investors (Ahearne, Griever and Warnock 2004; French and Poterba 1991), a possible reason for this relevance of home country religion might be that the financial value of a stock's Shari'ah compliance is positively related to the influence of Shari'ah law on consumers in its home economy. This explanation is supported by the observation that Islamic funds from those Islamic economies perform best (Qatar, UAE), whose dominant Islamic school of thought most literally follows the letters of Qur' an. ${ }^{14}$

\footnotetext{
${ }^{14} \mathrm{UAE}$ and Qatar are the only two predominantly Islamic economies, whose Islamic funds significantly outperform their international equity benchmarks on average. UAE and Qatar are also two of three Islamic countries in our sample, who closely follow the most literal Islamic school of thought (Hanbali). The third 'Hanbali' country is Saudi-Arabia. As shown in Table 5, Saudi Arabia's Islamic funds could outperform their equity market benchmarks on average, if their fund managers would be more successful in timing their market risk exposure based on economic fundamentals. Hence, we carefully conclude that the most literal Islamic school of thought, Hanbali, might have a positive effect on Islamic fund performance.
} 
The three level Carhart model also allows a precise assessment of Islamic funds' geographical investment focus and international investment style. Islamic funds from Singapore, Bahrain, Kuwait, Saudi Arabia, Germany, Ireland, Luxembourg, the UK, and the US invest at the national, regional and global level. Funds from the other countries tend to invest at their national level and at the regional or global level, whereby the regional investment might be limited to small cap stocks.

Funds from Islamic economies display a clear tendency to small cap investment at the national, regional, and global level. This observation supports our argument that an Islamic fund invests less likely in large companies due to their higher risk of receiving intolerable proportions of revenue from prohibited activities. At the regional and global level, this observation might also be explained by the home bias of funds from Islamic economies, as these economies often host comparatively small corporations. Islamic funds' preference for growth stocks in our national Carhart model has weakened after controlling for international investment style. Nevertheless, the average Islamic fund remains titled towards growth stocks, which likely results from the lower leverage of growth stocks compared to value stocks. As in the national Carhart model, Islamic funds show no tendency towards either momentum or contrarian investment in our three level Carhart model.

[Insert Table 4 about here]

\subsection{Conditional three level Carhart model}

Major macroeconomic variables have found to be useful predictors of equity market returns. If fund managers would vary their equity market exposure over time according to these public information variables, they could achieve a significant improvement in their alpha based on public information. Such a potential achievement would be unrelated to and hence artificially inflate the financial performance resulting 
from a mutual fund's decision to pursue an Islamic investment strategy. Hence, we control for this opportunity by conditioning our model on lagged public information variables based on Ferson and Schadt's (1996) approach. Specifically, we add the product of the non-orthogonalized global equity market excess return over the risk free rate $\left(\mathrm{r}_{\text {globalm,t }}\right)$ and a column vector of lagged public information variables $\left(\mathrm{z}_{\mathrm{t}-1}\right)$ to equation (3).

We choose the same type of lagged information variables as Renneboog et al. (2008) in their analysis of socially responsible mutual funds' time varying factor exposure and collect them from Datastream. These variables are: (i) the yield of the three month US treasury-bill; (ii) the term spread calculated as the difference between the ten year US government bond yield and the three month US treasury-bill; (iii) the default spread being the difference between Moody's US BAA rated corporate bond yield and its AAA rated equivalent; and (iv) the dividend yield of Datastream's world equity market index. Following Cortez et al. (2009), we increase the information value of our lagged information variables by detrending them from their twelve month moving average and address multicollinearity by transforming the results in mean zero values. ${ }^{15}$ Our resulting conditional model is displayed in equation (4),

$$
\begin{aligned}
& r_{p, t}=\alpha_{p}+\beta_{l e v, p}^{\prime} r_{l e v m, t}+\gamma_{l e v, p}^{\prime} S M B_{l e v, t}+\delta_{l e v, p}^{\prime} H M L_{l e v, t}+\lambda_{l e v, p}^{\prime} M O M_{l e v, t} \\
& +\theta_{p}^{\prime}\left(z_{t-1} r_{\text {globalm }, t}\right)+\varepsilon_{p, t}
\end{aligned}
$$

where $r_{\text {levm,t }}, \mathrm{SMB}_{\text {lev,t }}, \mathrm{HML}_{\text {lev,t }}$ and $\mathrm{MOM}_{\text {lev,t }}$ are column vectors, which include the respective factor at the national, regional, and global level. Consequentially, $\beta^{\prime}$ lev,p, $\gamma^{\prime}{ }_{\text {lev,p }}, \delta^{\prime}{ }_{\text {lev,p }}$, and $\lambda^{\prime}{ }_{\text {lev,p }}$ are row vectors of the coefficients attached to these factors.

\footnotetext{
${ }^{15}$ Cortez et al.'s (2009) mean zero value transformation addresses some but not all multicollinearity in our sample. Hence, we also pursue a three step orthogonalization procedure. First, we orthogonalize the product involving the treasury-bill from its terms spread equivalent. Second, we orthogonalize the product including the dividend yield from its cleaned treasury bill and its term spread equivalent. Third, we orthogonalize the product based on the default spread from its cleaned dividend yield, cleaned treasury-bill and term spread equivalent. Eventually, we use the product involving the cleaned default spread, the cleaned dividend yield, the cleaned treasury-bill and the term spread.
} 
$\theta^{\prime}{ }_{\mathrm{p}}$ is a row vector of coefficients attached to the product of the lagged information variables and the excess return of the global equity market.

Table 5 displays the alpha and beta coefficients of our conditional three level Carhart model. Generally, these coefficients ensure us that our results are robust to managerial timing activities and hence do not represent an artefact of them. Particularly, a comparison of our conditional model to its unconditional equivalent shows that only three alpha coefficients change their significance in inconsistent directions, which does not indicate any systematic relationship. Hence, most Islamic mutual fund managers either do not time their global equity market exposure based on lagged public information about macroeconomic variables or they fail to significantly benefit from it.

Comparing the difference in the conditional and unconditional global equity market exposures of national portfolios allows us to distinguish between both explanations. In the vast majority of countries, the difference is marginal, which implies that Islamic mutual funds managers, on average, do not attempt to time their global market exposure based on lagged public information. However, the conditional global equity market exposure of Islamic funds from Bahrain, Qatar and Saudi Arabia is substantially lower than their unconditional equivalent. This suggests that Islamic fund managers from these nations vary their portfolio's exposure according to public information variables but do not gain from it, as their abnormal returns in the unconditional model are not substantially better than in its conditional equivalent.

[Insert Table 5 about here] 


\section{Robustness tests ${ }^{16}$}

We pursue two further robustness tests in addition to our conditional three level Carhart model. First, our results might be an artefact of our sample period. If this would be the case, our results should be considerably different over other sample periods. To investigate this possibility, we re-estimate our three level Carhart model over various sample periods. We find our results to be highly consistent over time.

Second, the financial performance and investment style of Islamic funds in many of our sample countries might not result from the funds' Shari'ah compliance but from the sample countries' capital market restrictions. To test this explanation, we investigate the effect of the capital market restrictions listed in Table 2 on Islamic funds' financial performance and investment style during our respective nations' sample periods. We perform this analysis by adding a dummy variable to our three level Carhart model, which is set to one during restrictions and to zero thereafter or before. When a country imposed multiple capital market restrictions like Malaysia, we run one regression or each restriction. We do not find capital market restrictions to have any meaningful effect on our financial performance and investment style results in all of our sample countries except Singapore. In Singapore, the inbound restrictions before January 2002 are very likely the reason for the significant outperformance of its Islamic fund portfolio.

\section{Conclusion}

In this study, we analyse and compare the financial performance and investment style of Islamic equity funds from twenty countries. As Islamic funds often have diverse investment regions, we develop a (conditional) three level Carhart model to simultaneously control for a fund's exposure to different national, regional and global equity markets and investment styles.

\footnotetext{
${ }^{16}$ The results of the further robustness tests are available upon request.
} 
Our findings do not allow us to conclude that Islamic funds in general underor outperform equity markets. Instead, we find national characteristics to explain the heterogeneity in Islamic fund performance. Islamic funds from the six largest Islamic financial centres in our study (the GCC countries and Malaysia) perform competitive or even outperform international equity market benchmarks. Contrary, Islamic fund portfolios from most other nations with less developed Islamic financial services significantly underperform their benchmarks. Especially Islamic funds from predominantly Christian economies trail their benchmarks.

Our results have several implications. First, Islamic funds benefit from proximity to Islamic financial centres, as this seems to allow them to develop more expertise. Second, Islamic funds appear to have a financial advantage in Muslim economies. This might result from a higher utility, which consumers and agents in those economies receive from the Shari'ah compliance of assets. Third, governments can increase the attractiveness of Islamic funds in their jurisdiction by developing Islamic financial markets.

Islamic funds' international investment style appears somewhat tilted towards growth investing, which might result from growth stocks' under-proportional leverage. Funds from predominantly Muslim economies also display a clear small cap preference. This preference likely reflects the higher risk of large, well diversified corporations to operate in sectors forbidden by Shari' ah law.

We see at least three interesting routes for future research. First, once sufficient data for the majority of Islamic funds' host nations becomes acquirable, comparing the performance of Islamic funds with size and age matched conventional funds should lead to more insights in the attractiveness of active Islamic investment. Second, an in-depth exploration of the specific processes, by which developed Islamic 
financial markets support Islamic mutual funds, could substantially improve our understanding of Islamic financial services and allow government to grow these more effectively. Third, it has been beyond the scope of this paper to investigate Islamic mutual funds, which do not predominantly invest in stocks. However, hundreds of Islamic mutual funds focus their investment strategies on Islamic bonds, real estate or commodities. These funds' financial performance and investment styles appear academically unexplored to date and hence may be promising routes for future research.

\section{References}

Abderrezak, F. 2008. The performance of islamic equity funds. Falaika. http://www.failaka.com/downloads/AbderrezakF_Perf_IslamicEquityFunds.pdf.

Abdullah, F., T. Hassan and S. Mohamad. 2007. Investigation of performance of malaysian islamic unit trust funds. Managerial Finance, 33, no. 2: 142-153.

Ahearne, A. G., W. L. Griever and F. E. Warnock. 2004. Information costs and home bias: An analysis of us holdings of foreign equities. Journal of International Economics, 62, no. 2: 313-336.

Bauer, R., K.G. Koedijk and R. Otten. 2005. International evidence on ethical mutual fund performance and investment style. Journal of Banking \& Finance, 29: 1751-1767.

Bollen, N. P. B. 2007. Mutual fund attributes and investor behavior. Journal of Financial and Quantitative Analysis, 42, no. 3: 683-708.

Bollen, N. P. B. and J. A. Busse. 2001. On the timing ability of mutual fund managers. Journal of Finance, 56, no. 3: 1075-1094.

Campbell, J. Y. and T. Vuolteenaho. 2004. Bad beta, good beta. American Economic Review, 94, no. 5: 1249-1275.

Carhart, M. M. 1997. On persistence in mutual fund performance. Journal of Finance, 52, no. 1: 57-82.

Carhart, M. M., J. N. Carpenter, A. W. Lynch and D. K. Musto. 2002. Mutual fund survivorship. Review of Financial Studies, 15, no. 5: 1439-1463.

Christoffersen, S.E.K. and S. Sarkissian. 2009. City size and fund performance. Journal of Financial Economics, 92: 252-275.

Cihák, M. and H. Hesse. 2008. Islamic banks and financial stability: An empirical analysis. IMF Working Paper No. http://papers.ssrn.com/sol3/papers.cfm?abstract_id=1089682. 
Cortez, M. C., F. Silva and N. Areal. 2009. The performance of european socially responsible funds. Journal of Business Ethics, 87, no. 4: 573-588.

Da, Z., P. Gao and R. Jagannathan. 2009. Informed trading, liquidity provision, and stock selection by mutual funds. NBER Working Paper 14609.

Derigs, U. and S. Marzban. 2008. Review and analysis of current shariah-compliant equity screening practices. International Journal of Islamic and Middle Eastern Finance and Management, 1, no. 4: 285-303.

Derigs, U. and S. Marzban. 2009. New strategies and a new paradigm for shariahcompliant portfolio optimization. Journal of Banking \& Finance, 33, no. 6: 1166-1176.

Dow Jones. 2009. Dow jones islamic market (djim) indexes. Dow Jones \& Company. http://www.djindexes.com/islamic/index.cfm?go=overview.

Ebrahim, M. S. 2008. The financial crisis: Comments from islamic perspectives. IIUM Journal of Economics and Management, 16, no. 2: 111-118.

Ebrahim, M. S. and S. Rahman. 2005. On the pareto-optimality of futures contracts over forward contracts: Implications for emerging muslim economies. Journal of Economic Behavior and Organization, 56, no. 2: 273-295.

El-Gamal, M. A. 2006. Islamic finance: Law, economics and practice. Cambridge: Cambridge University Press.

Elfakhani, S., M. K. Hassan and Y. Sidani. 2005. Comparative performance of islamic versus secular mutual funds. Working Paper, University of New Orleans. http://www.business.uno.edu/econ/workingpapers/2006WP/10-

IslamicMutualFunds.pdf.

Elton, E. J., M. J. Gruber, S. Das and M. Hlavka. 1993. Efficiency with costly information: A reinterpretation of evidence from managed portfolios. Review of Financial Studies, 6, no. 1: 1-22.

Fama, E. F. and K. R. French. 1993. Common risk factors in the returns on stocks and bonds. Journal of Financial Economics, 33, no. 1: 3-53.

Ferson, W. and R. Schadt. 1996. Measuring fund strategy and performance in changing economic conditions. Journal of Finance, 51, no. 2: 425-461.

Forte, G. and F. Miglietta. 2007. Islamic mutual funds as faith-based funds in a socially responsible context. Working Paper, Department of Finance, Bocconi University.

http://papers.ssrn.com/sol3/papers.cfm?abstract_id=1012813\#PaperDownload.

French, K. R. and J. M. Poterba. 1991. Investor diversification and international equity markets. American Economic Review, 81, no. 2: 222-226.

Geczy, C. C., R. F. Stambaugh and D. Levin. 2005. Investing on socially responsible mutual funds. Working Paper, The Rodney L. White Center of Financial Research, The Wharton School, University of Pennsylvania. http://papers.ssrn.com/sol3/papers.cfm?abstract_id=416380 
Ghoul, W. and P. Karam. 2007. Mri and sri mutual funds: A comparison of christian, islamic (morally responsible investing), and socially responsible investing (sri) mutual funds. Journal of Investing, Summer 2007: 96-102.

Girard, E. and M. K. Hassan. 2008. Is there a cost to faith-based investing: Evidence from ftse islamic indices. Journal of Investing, 17, no. 4: 112-121.

Gregory, A. and J. Whittaker. 2007. Performance and performance persistence of 'ethical' unit trusts in the uk. Journal of Business Finance \& Accounting, 34, no. 7-8: 1327-1344.

HM Treasury. 2008. The development of islamic finance in the uk: The government's perspective. British Crown. http://www.hmtreasury.gov.uk/d/islamic_finance101208.pdf.

Hong, H. and M. Kacperczyk. 2009. The price of sin: The effects of social norms on markets. Journal of Financial Economics, 93, no. 1: 15-36.

Jaffer, S. 2004. Islamic asset management: Forming the future for shariah-compliant investment strategies. London: Euromoney Books.

Jarque, C. M. and A. K. Bera. 1987. A test for normality of observations and regression residuals. International Statistical Review, 55, no. 2: 163-172.

Jensen, M. C. 1968. The performance of mutual funds in the period 1945-1964. Journal of Finance, 23, no. 2: 389-416.

Kosowski, R., A. Timmermann, R. Wermers and H. White. 2006. Can mutual fund "Stars" Really pick stocks: New evidence from a bootstrap analysis. Journal of Finance, 61, no. 6: 2551-2595.

Kraeussl, R. and R. Hayat. 2008. The performance of islamic equity funds. Working Paper, Vrije University Amsterdam. http://papers.ssrn.com/sol3/papers.cfm?abstract_id=1320712.

Kreander, N., R. H. Gray, D. M. Power and C. D. Sinclair. 2005. Evaluating the performance of ethical and non-ethical funds: A matched pair analysis. Journal of Business Finance \& Accounting, 32, no. 7; 8: 1465-1493.

Lee, D. D. and R. W. Faff. 2009. Corporate sustainability performance and idiosyncratic risk: A global perspective. The Financial Review, 44, no. 2: 213237.

Lintner, J. 1965. The valuation of risk assets and the selection of risky investments in stock portfolios and capital budgets. Review of Economics and Statistics, 47, no. 1: $13-37$.

Magud, N. and C. M. Reinhart. 2006. Capital controls: An evaluation. NBER Working Paper 11973.

McKenzie, D. 2009. Islamic finance 2009. International Financial Services London. http://www.ifsl.org.uk/output/ReportItem.aspx?NewsID=32. 
Meesok, K., I.H. Lee, O. Liu, Y. Khatri, N. Tamirisa, M. Moor and M.H. Krysl. 2001. Malaysia: From crisis to recovery. International Monetary Fund Occassional Paper 207.

Mossin, J. 1966. Equilibrium in a capital asset market. Econometrica, 34, no. 4: 768783.

Newey, W. K. and K. D. West. 1987. A simple, positive semi-definite, heteroskedasticity and autocorrelation consistent covariance matrix. Econometrica, 55, no. 3: 703-708.

Rahail, A. 2008. Islamic finance: A practical guide. London: Globe Law and Business.

Renneboog, L., J. Ter Horst and C. Zhang. 2008. The price of ethics and stakeholder governance: The performance of socially responsible mutual funds. Journal of Corporate Finance, 14, no. 3: 302-322.

Sharpe, W. F. 1964. Capital asset prices: A theory of market equilibrium under conditions of risk. Journal of Finance, 19, no. 3: 425-442. 
Table 1. Descriptive statistics of Islamic mutual fund sample

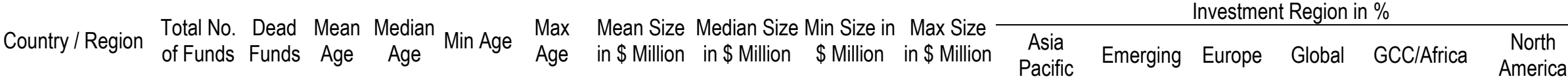

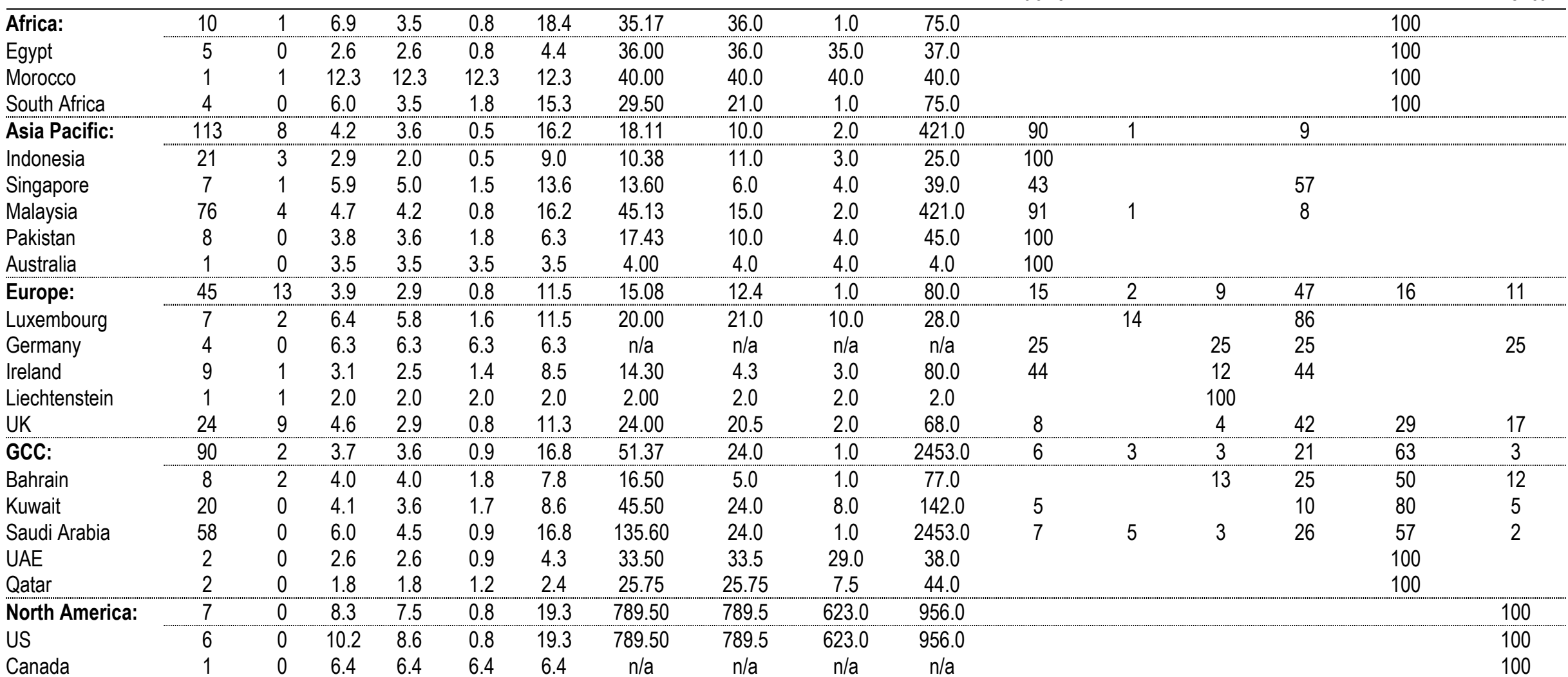

Note: This table reports national and regional descriptive statistics for all Islamic Fund portfolios in our sample. The first two columns show the total number of funds and the dead funds included in it. The next four columns display the mean, median, minimum, and maximum age of our sample funds in the respective nation or region. The following for column provide the equivalent information for fund size. In case Eurekahedge does not report the size for any fund in a portfolio, we report n/a. Otherwise, we report the descriptive statistics based on the number of funds, for which Eurekahedge reports size data. The last six columns report the geographical investment focus of the national and regional portfolios based on Eurekahedge's six categories. 
Table 2. Overview on sample countries' relevant characteristics

\begin{tabular}{|c|c|c|c|c|c|}
\hline Country / Region & $\begin{array}{c}\% \text { of } \\
\text { Muslims in } \\
\text { population }\end{array}$ & $\begin{array}{l}\text { Islamic } \\
\text { School of } \\
\text { Thought }\end{array}$ & $\begin{array}{l}\text { Islamic } \\
\text { assets } \\
\text { (in \$bn) }\end{array}$ & $\begin{array}{c}\text { Index of Shari'ah } \\
\text { compliance of listed } \\
\text { stocks (DJIM based) }\end{array}$ & Relevant financial market restrictions \\
\hline
\end{tabular}

Africa:

\begin{tabular}{|c|c|c|c|c|}
\hline Egypt & $90 \%$ & $\begin{array}{c}\text { Hanafi/ } \\
\text { Shafi }\end{array}$ & 5.7 & 0.33 \\
\hline Morocco & $98.7 \%$ & Maliki & $<5$ & -0.03 \\
\hline South Africa & $1.5 \%$ & $\mathrm{n} / \mathrm{a}$ & $<5$ & 0.37 \\
\hline \multicolumn{5}{|l|}{ Asia Pacific: } \\
\hline Indonesia & $86.1 \%$ & Shafi & $<5$ & 0.41 \\
\hline Singapore & $14.9 \%$ & $\mathrm{n} / \mathrm{a}$ & $<5$ & -0.32 \\
\hline Malaysia & $60.4 \%$ & Shafi & 65.7 & 0.11 \\
\hline Pakistan & $95 \%$ & Hanafi & 6.3 & $\mathrm{n} / \mathrm{a}$ \\
\hline Australia & $1.7 \%$ & $\mathrm{n} / \mathrm{a}$ & $<5$ & 0.12 \\
\hline \multicolumn{5}{|l|}{ Europe: } \\
\hline Luxembourg & $1.1 \%$ & $\mathrm{n} / \mathrm{a}$ & $<5$ & $\mathrm{n} / \mathrm{a}$ \\
\hline Germany & $3.7 \%$ & $\mathrm{n} / \mathrm{a}$ & $<5$ & -0.52 \\
\hline Ireland & $0.01 \%$ & $\mathrm{n} / \mathrm{a}$ & $<5$ & -1.88 \\
\hline Liechtenstein & $3.4 \%$ & $\mathrm{n} / \mathrm{a}$ & $<5$ & $\mathrm{n} / \mathrm{a}$ \\
\hline UK & $2.7 \%$ & $\mathrm{n} / \mathrm{a}$ & 18.1 & -0.005 \\
\hline
\end{tabular}

The Capital Market Law 95 of June 1992 and the Banking Law of June 2003 grant foreigners full access to capital markets. However, under Egyptian laws and regulations companies can adopt by-laws limiting or prohibiting foreign ownership of shares.

The Casablanca Stock Exchange places no restrictions on foreign participation. In contrast, the market is buoyed by strict restrictions on the ability of Moroccan individuals and institutions to invest abroad.

South African investment funds can invest 25 percent of their retail assets in other countries.

In September 1997, the Government of Indonesia removed the 49 percent limit on foreign ownership of companies' shares listed on the Jakarta and Surabaya Stock Exchanges.

In January 2002, Singapore removed all trading restrictions on foreign-owned stockbrokers.

As reaction to the Asian financial crisis, Malaysia imposed strict controls on the repatriation of foreign portfolio capital in September 1998. These controls were eased in subsequent years and fully removed in May 2001.

Similarly in September 1998, the Malaysian government required all foreign holdings of Malaysian Ringgit to be repatriated, virtually prohibited offshore Ringgit transactions and imposed tight controls on foreign investments.

In December 2002, Malaysia abolished the foreign currency limit on its residents' foreign investments. In April 2005 , Malaysian mutual funds were allowed to invest abroad $100 \%$ of their net asset value (NAV) attributable to foreigners and 30\% of their NAV attributable to residents. Since March 2007, mutual funds are allowed to invest up to $50 \%$ of their NAV attributable to residents.

Since 1991, the Government of Pakistan commenced the process of privatisation of previously nationalised financial institutions and actively seeks foreign investment in the Karachi Stock Exchange. 


\begin{tabular}{|c|c|c|c|c|c|}
\hline Country / Region & $\begin{array}{c}\% \text { of } \\
\text { Muslims in } \\
\text { population }\end{array}$ & $\begin{array}{l}\text { Islamic } \\
\text { School of } \\
\text { Thought }\end{array}$ & $\begin{array}{l}\text { Islamic } \\
\text { assets } \\
\text { (in \$bn) }\end{array}$ & $\begin{array}{l}\text { Index of Shari'ah } \\
\text { compliance of listed } \\
\text { stocks (DJIM based) }\end{array}$ & Relevant financial market regulations \\
\hline \multicolumn{6}{|l|}{ GCC: } \\
\hline Bahrain & $81.2 \%$ & Maliki & 37.1 & 0.89 & $\begin{array}{l}\text { The Bahrain Stock Exchange (BSE) allows persons from the Gulf Cooperative Council (GCC) to own up to } 100 \\
\text { percent of listed Bahraini companies. Non GCC firms/persons may own up to } 49 \text { percent of listed Bahraini } \\
\text { companies and } 100 \text { percent of foreign companies. }\end{array}$ \\
\hline Kuwait & $85 \%$ & Maliki & 54.0 & 0.45 & Since September 2000, Kuwait allows foreigners to invest in the Kuwait Stock Exchange. \\
\hline Saudi Arabia & $100 \%$ & Hanbali & 91.2 & $\mathrm{n} / \mathrm{a}$ & $\begin{array}{l}\text { The trading of shares in the Saudi Stock Exchange (SSE) is limited to the nationals of Saudi Arabia and people } \\
\text { belonging to the GCC. Since November 1997, foreign investors can enter the Saudi stock market through } \\
\text { mutual funds offered by (specific) Saudi banks. }\end{array}$ \\
\hline UAE & $96 \%$ & $\begin{array}{l}\text { Hanbali/ } \\
\text { Maliki }\end{array}$ & 48.2 & -0.21 & $\begin{array}{l}\text { Foreign investors may hold up to a } 49 \text { percent interest in limited liability companies, although company by-laws } \\
\text { in many cases prohibit foreign ownership. }\end{array}$ \\
\hline Qatar & $77.5 \%$ & Hanbali & 19.3 & 0.20 & $\begin{array}{l}\text { Qatar's regulations allow foreigners to invest in all Qatar Exchange listed companies unless this would lead the } \\
\text { foreign ownership of a company to exceed } 25 \text { percent. }\end{array}$ \\
\hline \multicolumn{6}{|l|}{ North America: } \\
\hline US & $0.6 \%$ & $\mathrm{n} / \mathrm{a}$ & $<5$ & 0.25 & \\
\hline Canada & $1.9 \%$ & $\mathrm{n} / \mathrm{a}$ & $<5$ & 0.31 & \\
\hline \multicolumn{6}{|c|}{ 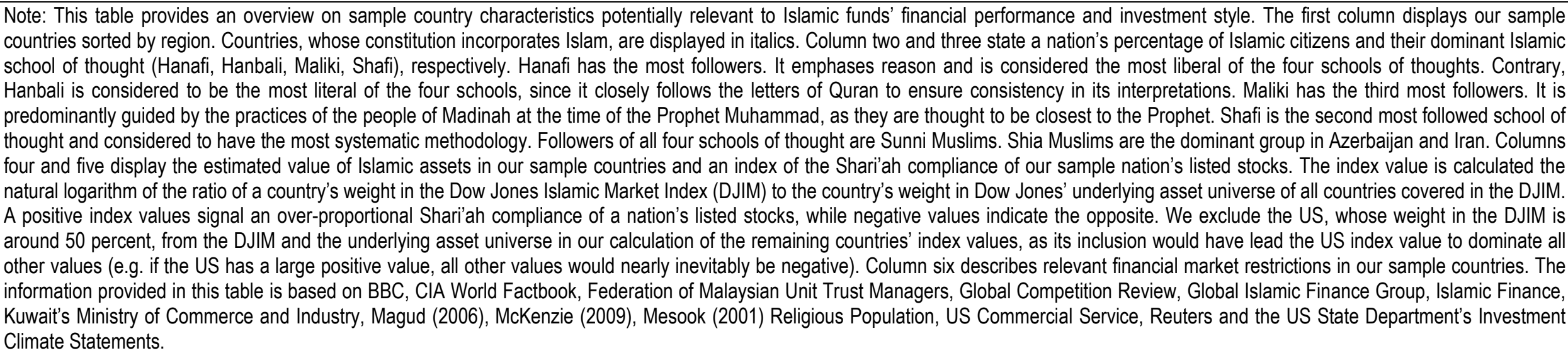 } \\
\hline
\end{tabular}


Table 3. National financial performance and investment style (CAPM and Carhart)

\begin{tabular}{|c|c|c|c|c|c|c|c|c|c|}
\hline \multirow{2}{*}{ Country / Region } & \multicolumn{2}{|c|}{ CAPM model } & \multicolumn{5}{|c|}{ Carhart Model } & \multirow{2}{*}{ Adj $R^{2}$ CAPM } & \multirow{2}{*}{ Adj $R^{2}$ Carhart } \\
\hline & $a_{p}$ & $\beta_{\text {nat }, p}$ & $a_{p}$ & $\beta_{\text {nat, } p}$ & $Y_{\text {nat, } p}$ & $\delta_{\text {nat }, p}$ & $\lambda_{\text {nat, } p}$ & & \\
\hline \multicolumn{10}{|l|}{ Africa: } \\
\hline Egypt & $-0.0079 * *$ & $0.6468^{* * *}$ & $-0.0075^{* *}$ & $0.6587^{* * *}$ & 0.1768 ** & -0.0781 * & 0.0509 & 0.842 & 0.852 \\
\hline Morocco & $-0.0149 * * *$ & $0.4179 * * *$ & $-0.0136 * * *$ & $0.4238 * * *$ & $0.3521 * * *$ & $0.2304 * * *$ & -0.0886 & 0.220 & 0.320 \\
\hline South Africa & $-0.0092 * * *$ & $0.8348^{* * *}$ & $-0.0081 * * *$ & $0.8657^{* * *}$ & $0.2299 * * *$ & 0.0571 & 0.0465 & 0.850 & 0.865 \\
\hline \multicolumn{10}{|l|}{ Asia: } \\
\hline Indonesia & -0.0013 & $0.3290 * * *$ & 0.0005 & $0.3579 * * *$ & 0.1200 * & -0.1824 ** & 0.0454 & 0.611 & 0.648 \\
\hline Singapore & -0.0024 & $0.3019 * * *$ & -0.0003 & $0.3240 * * *$ & $0.2939 * * *$ & -0.2351 *** & $0.0724 * *$ & 0.267 & 0.371 \\
\hline Malaysia & -0.0034 & $0.3564 * * *$ & -0.0039 * & $0.3289 * * *$ & -0.0666 & 0.0464 & -0.0682 & 0.427 & 0.437 \\
\hline Pakistan & -0.004 & $0.4985^{* * *}$ & -0.0047 & $0.5096 * * *$ & 0.0774 & -0.0058 & 0.0303 & 0.720 & 0.714 \\
\hline Australia & -0.0155 & $0.4260 * * *$ & -0.0146 & $0.3598 * * *$ & 0.4764 * & -0.2159 & -0.3538 & 0.124 & 0.113 \\
\hline \multicolumn{10}{|l|}{ Europe: } \\
\hline Luxembourg & $-0.0081^{* * *}$ & $0.6592^{* * *}$ & $-0.0078^{* * *}$ & $0.6747^{* * *}$ & -0.0094 & $-0.0933 * * *$ & 0.0412 * & 0.656 & 0.683 \\
\hline Germany & $-0.0101^{* * *}$ & $0.6523^{* * *}$ & $-0.0088 * * *$ & $0.7710 * * *$ & 0.1209 * & -0.0985 & $0.1300 * *$ & 0.695 & 0.726 \\
\hline Ireland & 0.00136 & $0.4784^{* * *}$ & 0.0001 & 0.5166 *** & 0.1109 ** & -0.0057 & 0.0128 & 0.562 & 0.570 \\
\hline Liechtenstein & -0.0078 * & $0.4065^{* * *}$ & $-0.0097^{* *}$ & $0.4122 * * *$ & $0.8321 * * *$ & $-0.3200 * *$ & -0.8538 *** & 0.104 & 0.345 \\
\hline UK & $-0.0081 * * *$ & $0.7038^{* * *}$ & $-0.0087^{* * *}$ & $0.7014 * * *$ & 0.1158 ** & $-0.2092 * * *$ & $-0.0615^{* *}$ & 0.702 & 0.728 \\
\hline \multicolumn{10}{|l|}{ GCC: } \\
\hline Bahrain & -0.0003 & $0.4156^{* *}$ & -0.0028 & $0.6102 * * *$ & 0.0552 & $-0.1173^{* * *}$ & 0.0358 * & 0.294 & 0.465 \\
\hline Kuwait & -0.0019 & $0.5879^{* * *}$ & -0.0024 & $0.5813^{* * *}$ & 0.0782 & 0.0255 & -0.0148 & 0.653 & 0.648 \\
\hline Saudi Arabia & -0.0248 * & $0.8974^{* * *}$ & $-0.0252 *$ & $1.0249 * * *$ & 0.1671 & 0.2014 & -0.0520 & 0.425 & 0.418 \\
\hline UAE & 0.00301 & $0.7146^{* * *}$ & 0.0083 * & $0.8310 * * *$ & 0.0496 & -0.1637 ** & 0.0334 & 0.807 & 0.832 \\
\hline Qatar & -0.0061 & $0.6924 * * *$ & -0.0059 & 0.6913 *** & 0.1931 & -0.0792 & 0.0369 & 0.829 & 0.813 \\
\hline \multicolumn{10}{|l|}{ North America: } \\
\hline US & $-0.0045^{* * *}$ & 0.8568 *** & $-0.0052^{* * *}$ & $0.8288 * * *$ & 0.1574 ** & $-0.0841^{* *}$ & 0.0434 * & 0.840 & 0.855 \\
\hline Canada & -0.0029 & $0.7245^{* * *}$ & $-0.0040 *$ & $0.7669 * * *$ & 0.0208 & 0.0429 & -0.0252 & 0.732 & 0.736 \\
\hline
\end{tabular}


Table 4. International financial performance and investment style (three level carhart model)

\begin{tabular}{|c|c|c|c|c|c|c|c|c|c|c|c|c|c|c|}
\hline \multirow{2}{*}{$\begin{array}{l}\text { Country/ } \\
\text { Region }\end{array}$} & \multirow{2}{*}{$\begin{array}{l}\text { Intercept } \\
a_{p}\end{array}$} & \multicolumn{3}{|c|}{ Market exposures } & \multicolumn{3}{|c|}{ SMB exposures } & \multicolumn{3}{|c|}{ HML exposures } & \multicolumn{3}{|c|}{ MOM exposures } & \multirow{2}{*}{ Adj $R^{2}$} \\
\hline & & $\beta_{\text {nat,p }}$ & $\beta_{\text {reg,p }}$ & $\beta_{\mathrm{glo}, \mathrm{p}}$ & $Y_{\text {nat, } p}$ & $\gamma_{\text {reg, }, p}$ & Yglop & $\delta_{\text {nat }}$ & $\delta_{\text {reg } p}$ & $\delta_{g l o p}$ & $\lambda_{\text {nat, } p}$ & $\lambda_{\text {reg p }}$ & $\lambda_{\text {reg } p}$ & \\
\hline \multicolumn{15}{|l|}{ Africa: } \\
\hline Egypt & -0.0018 & $0.6234^{* * *}$ & 0.1058 * & 0.1611 & $0.1500 * *$ & 0.2519 ** & 0.0428 & -0.0610 & $-0.1689 * * *$ & -0.0717 & 0.0311 & -0.0199 & 0.0709 & 0.839 \\
\hline Morocco & $-0.0115^{* * *}$ & $0.4223^{* * *}$ & 0.0377 & 0.1380 & 0.3488 *** & 0.0825 * & -0.0132 & $0.2307^{* * *}$ & -0.0994 * & 0.1108 & -0.0796 & -0.0212 & -0.0015 & 0.303 \\
\hline South Africa & $-0.0103^{* * *}$ & $0.8383^{* * *}$ & -0.0650 & 0.0525 & $0.2459 * * *$ & 0.0254 & 0.1770 * & 0.0498 & 0.0395 & 0.1578 ** & 0.0486 & -0.0010 & -0.0213 & 0.866 \\
\hline \multicolumn{15}{|l|}{ Asia: } \\
\hline Indonesia & -0.0005 & $0.3306 * * *$ & $0.2210^{* * *}$ & -0.0849 & 0.1670 ** & 0.3102 ** & -0.0738 & $-0.1811^{* * *}$ & -0.0532 & -0.0602 & 0.0609 & -0.1120 ** & -0.1041 * & 0.703 \\
\hline Singapore & $0.0087^{* * *}$ & $0.2753^{* * *}$ & $0.2939 * * *$ & $0.5068^{* * *}$ & 0.1614 *** & 0.0806 & 0.1997 & -0.1182 ** & $-0.3440^{* * *}$ & $-0.5075^{* * *}$ & 0.0690 ** & 0.0403 & -0.0451 & 0.678 \\
\hline Malaysia & -0.0027 & $0.3200^{* * *}$ & 0.0737 & 0.0676 & -0.0910 & 0.0974 & 0.2978 * & 0.0838 & $-0.1280^{* *}$ & $-0.1969 * *$ & -0.0712 & -0.0527 & 0.0039 & 0.443 \\
\hline Pakistan & -0.0031 & $0.5318^{* * *}$ & 0.0725 & 0.0993 & 0.1592 * & 0.1257 & 0.1675 & -0.0454 & -0.1429 & -0.4619 & 0.0374 & $-0.2147^{* *}$ & 0.1027 & 0.724 \\
\hline Australia & -0.0371 ** & 0.6258 * & -0.5027 & $-1.7047^{* *}$ & 0.4627 & -0.2354 & -2.1131 & 0.0674 & -0.6798 & -0.7334 & -0.1764 & $-0.6936^{* *}$ & 0.2971 & 0.155 \\
\hline \multicolumn{15}{|l|}{ Europe: } \\
\hline Luxembourg & -0.0034 ** & $0.6789 * * *$ & $0.8543^{* * *}$ & $0.4463^{* * *}$ & -0.0053 & -0.1153 * & -0.0780 & -0.0060 & -0.3446 *** & -0.4756 *** & 0.0194 & 0.0018 & -0.0244 & 0.905 \\
\hline Germany & $-0.0087^{* * *}$ & $0.6061^{* * *}$ & $0.9695^{* * *}$ & $0.4782^{* * *}$ & $-0.1439 * * *$ & 0.1777 & $0.6758^{* * *}$ & 0.0185 & 0.0873 & -0.1926 & 0.1596 *** & 0.1472 & 0.0577 & 0.839 \\
\hline Ireland & $0.0117^{* * *}$ & $0.4270^{* * *}$ & $0.6098^{* * *}$ & $0.4751^{* * *}$ & -0.0343 & 0.0905 & -0.1532 & -0.0131 & $0.2170^{* * *}$ & 0.1302 & 0.0002 & 0.0125 & $0.1791^{* *}$ & 0.794 \\
\hline Liechtenstein & -0.0266 ** & 0.2530 & 1.2253 ** & -1.3591 & 0.4395 & 0.1241 & 0.0013 & -0.2277 & 0.7497 & 0.3164 & -0.9588 ** & -0.0025 & 0.0928 & 0.436 \\
\hline UK & $-0.0145^{* * *}$ & $0.6147^{* * *}$ & $0.3764^{* * *}$ & $0.6192^{* * *}$ & 0.0251 & -0.0916 & 0.0180 & $-0.1287^{* * *}$ & -0.1031 * & $-0.2773^{* * *}$ & -0.0089 & 0.0471 & 0.0012 & 0.890 \\
\hline \multicolumn{15}{|l|}{ GCC: } \\
\hline Bahrain & 0.0032 & $0.4996 * * *$ & $0.4967^{* * *}$ & $0.3872^{* * *}$ & 0.0429 & 0.0636 & -0.0522 & $-0.0798 * * *$ & $0.0819^{* * *}$ & $-0.2637^{* *}$ & 0.0462 *** & -0.0441 ** & 0.0502 & 0.888 \\
\hline Kuwait & 0.0030 & 0.6786 *** & 0.2025 ** & $0.1817^{* *}$ & 0.0067 & 0.0333 & -0.3210 & 0.0204 & 0.1004 & -0.6539 ** & -0.0038 & -0.0422 & -0.1683 * & 0.699 \\
\hline Saudi Arabia & 0.0039 & $1.0100^{* * *}$ & $1.6277^{* * *}$ & $1.8272^{* * *}$ & 0.2532 & $0.2837^{*}$ & 0.4793 & 0.1069 & 0.0724 & -0.1774 & -0.0232 & -0.0374 & -0.4956 & 0.843 \\
\hline UAE & $0.0147^{* *}$ & 0.7884 *** & 0.1084 & 0.0912 & -0.0130 & $-0.3057^{* *}$ & -0.2866 & -0.1109 & -0.1836 * & -0.0406 & 0.0270 & $0.1463^{* * *}$ & 0.0090 & 0.877 \\
\hline Qatar & 0.0225 ** & 0.5224 *** & 0.3253 * & $0.4993^{* *}$ & 0.4614 * & -0.3292 & -0.1664 & -0.2431 * & -0.1385 & $0.8810^{* *}$ & 0.2069 & 0.1609 & -0.0503 & 0.806 \\
\hline \multicolumn{15}{|c|}{ North America: } \\
\hline US & $-0.0049 * * *$ & $0.8282 * * *$ & 3.0164 *** & $0.2294^{* * *}$ & 0.0725 & -0.7345 & -0.1282 * & -0.0838 ** & 0.5064 * & 0.0740 * & 0.0287 & 0.0095 & 0.0614 * & 0.877 \\
\hline Canada & 0.0013 & $0.7917^{* * *}$ & 0.0781 & 0.6866 ** & 0.0116 & -0.0950 & 0.1237 & 0.0621 * & 0.0908 & -0.2886 & -0.0186 & 0.0019 & -0.1127 & 0.764 \\
\hline
\end{tabular}

Note: This table reports the results of our three level Carhart Model, which we develop in equation (3). In short, our three level Carhart model estimates the exposure of a portfolio to (i) its national (Subscript nat) equity market and investment style benchmarks, (ii) to its regional (reg) equity market and investment style benchmarks, which are cleaned from the effects of its national equivalents, (iii) and the global equity market (glo) and investment style benchmarks, which are cleaned from the effects of its national and regional equivalents. After the intercept alpha, twelve coefficients are reported in groups of three. These display the national, regional, and global coefficients are attached to the respective equity market benchmark, the SMB, the HML and the MOM factor. The last coefficient presents the adjusted Rsquared statistic. Coefficient covariances and standard errors are made heteroscedasticity and autocorrelation consistent based on Newey and West (1987). ${ }^{* * *}$, ${ }^{* *}$, and ${ }^{*}$ indicate the $1 \%, 5 \%$, and $10 \%$ significance level, respectively. 
Table 5. International financial performance and investment style (conditional three level Carhart model)

\begin{tabular}{|c|c|c|c|c|c|}
\hline \multirow{2}{*}{ Country } & \multirow{2}{*}{$\begin{array}{l}\text { Intercept } \\
a_{p}\end{array}$} & \multicolumn{3}{|c|}{ Market exposures } & \multirow{2}{*}{ Adj $R^{2}$} \\
\hline & & $\beta_{\text {nat, } p}$ & $\beta_{\text {reg, } p}$ & $\beta_{g l o, p}$ & \\
\hline \multicolumn{6}{|l|}{ Africa: } \\
\hline Egypt & -0.0015 & $0.5898 * * *$ & 0.0972 & 0.0889 & 0.824 \\
\hline Morocco & $-0.0125^{* * *}$ & $0.4023 * * *$ & 0.0600 * & 0.2312 ** & 0.307 \\
\hline South Africa & $-0.0101^{* * *}$ & $0.8269 * * *$ & -0.0270 & 0.0152 & 0.865 \\
\hline \multicolumn{6}{|l|}{ Asia: } \\
\hline Indonesia & 0.0000 & $0.3096 * * *$ & 0.1284 ** & -0.0387 & 0.759 \\
\hline Singapore & $0.0094 * * *$ & $0.2660 * * *$ & $0.2883 * * *$ & $0.5082 * * *$ & 0.675 \\
\hline Malaysia & -0.0025 & $0.3236 * * *$ & 0.0651 & 0.0737 & 0.435 \\
\hline Pakistan & $-0.0061^{*}$ & 0.5176 *** & 0.2434 & 0.1565 & 0.731 \\
\hline Australia & -0.0424 ** & 0.5510 & -0.3580 & $-2.1355^{* *}$ & 0.049 \\
\hline \multicolumn{6}{|l|}{ Europe: } \\
\hline Luxembourg & $-0.0031^{*}$ & $0.6689 * * *$ & $0.8723 * * *$ & $0.4449 * * *$ & 0.904 \\
\hline Germany & $-0.0085^{* * *}$ & $0.5119 * * *$ & $0.8475^{* * *}$ & $0.4833^{* * *}$ & 0.863 \\
\hline Ireland & $0.0125^{* * *}$ & $0.3830 * * *$ & $0.5369 * * \star$ & $0.5510 * * *$ & 0.807 \\
\hline Liechtenstein & -0.0149 & 0.7049 & 1.8756 ** & -0.0860 & 0.574 \\
\hline UK & $-0.0131^{\star * *}$ & $0.5980 * * *$ & $0.2979 * * *$ & $0.5845^{* \star *}$ & 0.893 \\
\hline \multicolumn{6}{|l|}{ GCC: } \\
\hline Bahrain & 0.0035 & $0.4021^{* * *}$ & $0.4334^{* * *}$ & $0.2667^{* * *}$ & 0.908 \\
\hline Kuwait & 0.0044 & $0.4972 * * *$ & -0.0789 & -0.2018 & 0.745 \\
\hline Saudi Arabia & $0.0125 * *$ & $0.5743^{* * *}$ & $0.7509 * *$ & $0.8779 * * *$ & 0.935 \\
\hline UAE & 0.0126 * & $0.7949 * * *$ & 0.0840 & 0.1065 & 0.876 \\
\hline Qatar & 0.0208 * & 0.2475 & 0.0724 & -0.0348 & 0.798 \\
\hline \multicolumn{6}{|l|}{ North America: } \\
\hline US & -0.0046 *** & $0.8738 * * *$ & 3.1877 *** & 0.2568 *** & 0.886 \\
\hline Canada & -0.0014 & $0.8344^{* * *}$ & 0.1394 & 0.5444 * & 0.771 \\
\hline $\begin{array}{l}\text { Note: This table re } \\
\text { For brevity, we or } \\
\text { seventeen coeffici } \\
\text { autocorrelation cor } \\
\text { sianificance level. }\end{array}$ & $\begin{array}{l}\text { of the cond } \\
\text { pha followec } \\
t \text { covariance } \\
\text { n Newey anc }\end{array}$ & $\begin{array}{l}\text { al three leve } \\
\text { the national } \\
\text { d standard } \\
\text { st (1987). }\end{array}$ & $\begin{array}{l}\text { arhart Model } \\
\text { egional, and } \\
\text { rors are mac } \\
{ }^{*} \text {, and * indic }\end{array}$ & $\begin{array}{l}\text { played in eq } \\
\text { bal beta ins } \\
\text { heterosceda } \\
\text { the } 1 \%, 5 \%\end{array}$ & $\begin{array}{l}\text { ation (5). } \\
\text { ad of all } \\
\text { icity and } \\
\text { and } 10 \%\end{array}$ \\
\hline
\end{tabular}

